\title{
Palaeogeography and palaeoecology of early Floian (Early Ordovician) cephalopods from the Upper Fezouata Formation, Anti-Atlas, Morocco
}

\author{
Björn Kröger*, 1 and Bertrand Lefebvre ${ }^{2}$ \\ ${ }^{1}$ Museum für Naturkunde, Leibniz-Institut für Evolutions- und Biodiversitätsforschung, Invalidenstr. 43, 10115 Berlin, Germany. \\ E-mail: bjoekroe@gmx.de \\ ${ }^{2}$ Laboratoire de Géologie de Lyon "Terre, Planètes et Environnement", UMR CNRS 5276, Université Lyon 1 \& ENS-Lyon, Géode, \\ 2 rue Raphaël Dubois, 69622 Villeurbanne cedex, France
}

Received 9 September 2011

Accepted 28 December 2011

Published 3 August 2012

\begin{abstract}
In the central Anti-Atlas (Morocco), the Early Ordovician succession consists of about $1000 \mathrm{~m}$ of fossiliferous argillites and siltstones. The Upper Fezouata Formation (Floian) contains a comparatively rich and abundant cephalopod association. A small collection of these cephalopods is described herein for the first time. The cephalopods are interpreted as autochthonous or parautochthonous, representing a fauna, which originally lived nektobenthically in the open water above the sediments or related to the sea bottom. The cephalopod associations of the Upper Fezouata Formation are similar to other contemporaneous assemblages known from higher palaeolatitudes and associated with deeper depositional settings and in siliciclastically dominated deposits. They are composed almost exclusively of slender orthocones, in this case predominantly of Destombesiceras zagorense n. gen., n. sp., which is interpreted as an early discosorid. Bathmoceras australe Teichert, 1939 and Bathmoceras taichoutense n. sp. from the Upper Fezouata Formation are at present the earliest unambiguous occurrences of bathmocerid cephalopods. Epizoans on the shell of a specimen of Rioceras are the earliest evidence of bryozoans growing as potential hitchhikers on cephalopod shells, indicating an early exploitation of a pseudoplanktonic lifestyle in this phylum.
\end{abstract}

\section{Introduction}

This is the first description of Ordovician cephalopods from Morocco. Although their occurrence has been known for a long time, only a poorly preserved conch from the late Katian of Ikhf n'Ouzerg (central Anti-Atlas) was described as "Orthoceras hastile Barrande" by Termier \& Termier (1950). In some cases Ordovician cephalopods were mentioned within faunal lists without classification (e.g., Gutiérrez-Marco 2003; Destombes 2006a; Van Roy et al. 2010). Indeed, the lack of earlier works on Moroccan cephalopod assemblages does not reflect their absence or rarity. It rather is an expression of a neglect of the group by many palaeontologists working in the region. Generally, the Ordovician cephalopods of the high latitude margins of Gondwana are poorly known and, where known, often are in need of revision. Of those high latitudinal assemblages most recently revised or newly described in detail (Marek et al. 2000; Gnoli \& Pillola 2002; Evans 2005; Kröger \& Evans 2011), all seem to be characterized by the presence (often in abundance) of specific forms that are rare or absent in low palaeolatitude regions.

Contrary to the situation in most other high latitude (peri-)Gondwanan regions (e.g., Algeria, Bohemia, France, Spain), the first reports of Ordovician faunas in the Anti-Atlas, Morocco are relatively recent (Bigot \& Dubois 1931; Choubert 1952; Choubert et al. 1953). Intensive field work achieved by Jacques Destombes between 1959 and 1985 during the campaign of $1: 200,000$ mapping of the whole Anti-Atlas lead to a much improved stratigraphic framework, and to the collection of abundant fossil material (Destombes 1962, 1971; Destombes et al. 1985). In particular, extremely

* Corresponding author 
rich and diverse Early Ordovician marine assemblages were described from the Anti-Atlas, based on Destombes' material, including acritarchs and chitinozoans (Deunff 1968a, b; Elaouad-Debbaj 1984, 1988), bivalves and rostroconchs (Destombes \& Babin 1990), brachiopods (Havlicek 1971; Mergl 1981), echinoderms (Ubaghs 1963; Chauvel 1966, 1969, 1971a, b; Donovan \& Savill 1988), gastropods (Horny 1997), graptolites (Destombes \& Willefert 1959), hyolithids (Marek 1983), and trilobites (Destombes 1972; Vidal 1998a, b). Early Ordovician faunas from the Anti-Atlas exhibit strong affinities with other high-latitude assemblages, and in particular with those from the Montagne Noire (Southern France).

In the early 2000s, intensive field work in the Early Ordovician succession of Zagora area (central Anti-Atlas) lead to the discovery of several horizons yielding exceptionally preserved assemblages (Van Roy et al. 2010). This so-called Fezouata Biota contains not only fully articulated remains of skeletonised organisms (e.g., echinoderms: Lefebvre 2007; Noailles et al. 2010; Sumrall \& Zamora in press), but also extremely abundant and diverse remains of soft-bodied to lightly sclerotised invertebrates (e.g., annelids, anomalocaridids, machaeridians, marrellomorphs, sponges: Van Roy 2006; Van Roy \& Tetlie 2006; Botting 2007; Vinther et al. 2008; Van Roy \& Briggs 2011). These Lagerstätten provide an unprecedented opportunity to document the onset of the Great Ordovician Biodiversification Event (Servais et al. 2010), and the transition from the Cambrian Evolutionary Fauna to the Palaeozoic Evolutionary Fauna. They also offer for the first time the possibility to compare the well-known Early to MidCambrian marine communities (e.g., Chengjiang, Burgess Shale) with similarly preserved Ordovician assemblages.

The description of the Fezouata Formation cephalopods, which are generally considered as the top free swimming predators, will provide new information on this important element of the food web of the Fezouata Biota. A comparison with contemporaneous Gondwanan cephalopod assemblages will deepen our knowledge on the as yet poorly documented cephalopod faunas in high latitude regions in Early Ordovician times.

\section{Material and methods}

Most of the material described herein was collected in situ during two successive field campaigns (January 2003 and January 2004) in the Early Ordovician succession of the Zagora area. This material (marked as AA) is now deposited in the collections of Cadi Ayyad University, Marrakech (Faculté des Sciences et Techniques, Guéliz). In the early 2000s, additional specimens were collected by Roland and Véronique Reboul (Saint-Chinian). Their material is now deposited in the palaeontological collections of Lyon 1 University, Villeurbanne (FSL), the Musée des Confluences, Lyon (ML), and the Natural History Museum of Marseille (MHNM).

After taxonomic determination of the specimens, we estimated the diversity measures of the assemblage with the software Estimates Ver- sion 8.20 (Colwell 2009) and with the R-software package Vegan Version 1.15-2 (Oksanen et al. 2011).

\section{Geological setting and stratigraphic framework}

The study material was collected in situ from six different localities, all located within the central part of the Anti-Atlas, Morocco (Fig. 1). In the Zagora area, the Early Ordovician succession is weakly folded, and about $1000 \mathrm{~m}$ thick (Destombes et al. 1985; Destombes 2006b). Its lower part, the Lower Fezouata Formation (Tremadocian) consists of approximately $430 \mathrm{~m}$ of blue to greenish fine argillites resting unconformably over sandstones of the Azlag Formation (Tabanite Group, Middle Cambrian). The detailed stratigraphy of the Lower Fezouata Formation is relatively well constrained, based on its acritarch, chitinozoan, and graptolite assemblages (Destombes \& Willefert 1959; Deunff 1968a, b; Elaouad-Debbaj 1988). The overlying Upper Fezouata Formation (Floian) corresponds to about $570 \mathrm{~m}$ of yellow to greenish siltstones, containing (in its upper part) several levels with alumino-siliceous concretions. The uppermost part of the Upper Fezouata Formation was assigned to the late Floian (time slice

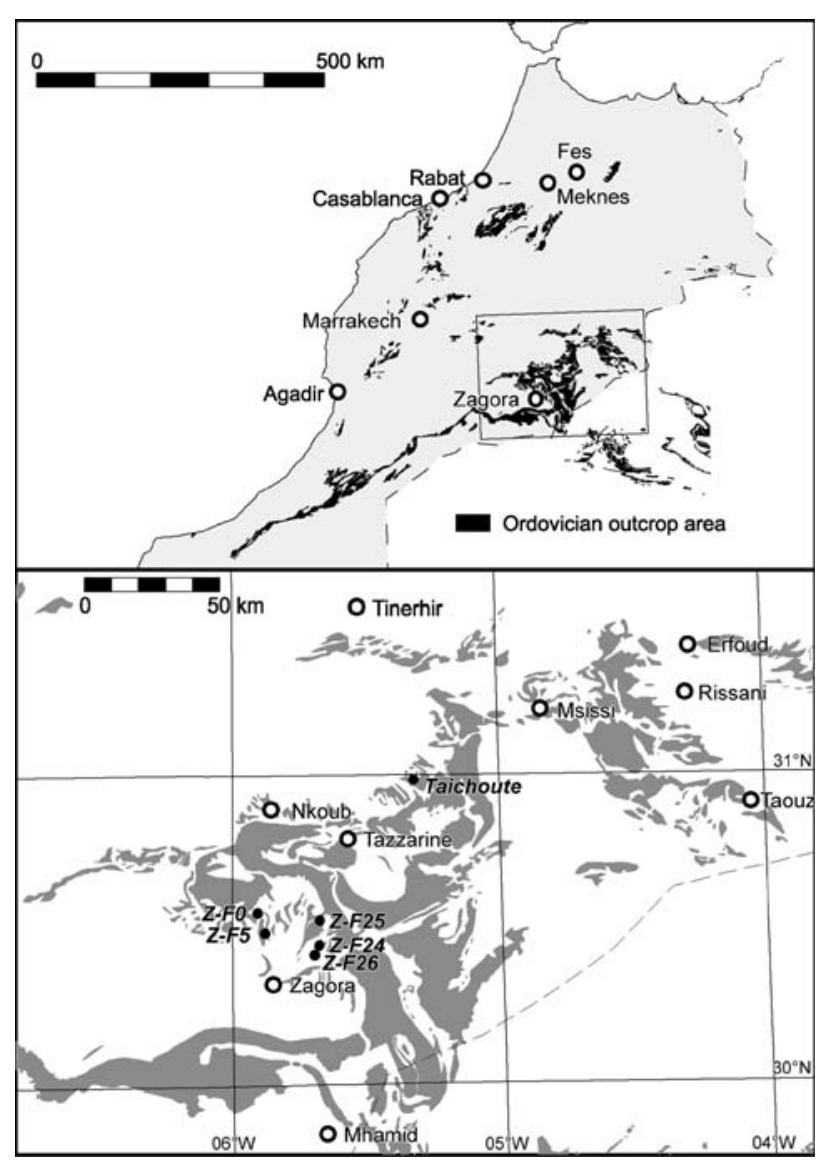

Figure 1. Generalized maps showing Ordovician outcrops in Morocco (top), and in central and eastern Anti-Atlas (bottom), with location of the six main cephalopod localities mentioned in text (modified from Lefebvre \& Botting 2007). 


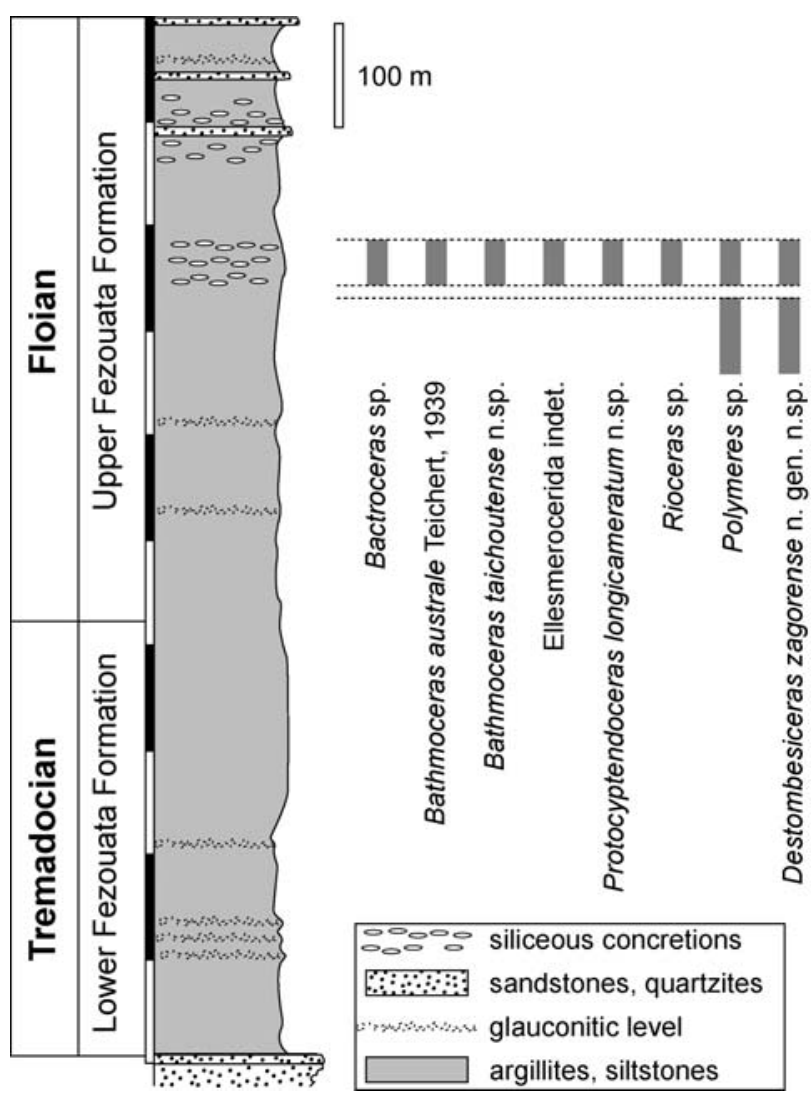

Figure 2. Stratigraphic ranges of cephalopods in the Early Ordovician of central Anti-Atlas (Zagora area). Stippled lines mark the two sampled stratigraphic intervals. Section modified from Vidal (1998a) and Destombes (2006b).

2c) based on the presence of the chitinozoan Eremochitina baculata brevis (Elaouad-Debbaj 1984). All fossils described herein were collected from two distinct stratigraphic intervals, both located within the Upper Fezouata Formation (Fig. 2).

The lower stratigraphic interval corresponds to micaceous siltstones located between 680 and $750 \mathrm{~m}$ above the base of the Ordovician succession. Graptolites (Baltograptus geometricus, B. vacilllans) are suggestive of an early Floian age (J. C. Gutiérrez-Marco, pers. comm., May 2003). The associated benthic fauna is particularly abundant and diverse, including various arthropods (e.g., aglaspidids, cheloniellids, Zagoracaris fezouataensis), bivalves (Babinka, Coxiconcha, Redonia), echinoderms (eocrinoids, rhombiferans, solutans, somasteroids, cornute and mitrate stylophorans), gastropods (Carcassonnella, Deshyolites, Lesueurilla, Thoralispira), hyolithids, machaeridians, rostroconchs (Ribeiria), trilobites (e.g., Agerina, Ampyx, Asaphellus, Colpocoryphe, Euloma, Harpides, Parabathycheilus, Prionocheilus, Selenopeltis, Toletanaspis), as well as "soft-bodied" organisms (e.g., various "worms") (Destombes et al. 1985; Van Roy et al. 2010). This assemblage occurs in the following four localities: Jbel Bou Zeroual (noted as "Z-F0" on specimen labels), Oued Beni Zoli ("Z-F5"), N. of Toumiat ("Z-F24"), and Toumiat ("Z-F26"). The most diverse benthic assemblages were collected in the yellow, micaceous siltstones of both Jbel Bou Zeroual (small quarry, about $26 \mathrm{~km}$ NNW of Zagora, W of Jbel Bou Dehir) and Toumiat (low cliff on the bank of a dried oued, about $18 \mathrm{~km} \mathrm{NE}$ of Zagora, E of Jbel Bou Dehir). The green micaceous siltstones of Oued Beni Zoli (low cliff on the bank of Oued Beni Zoli, about $17 \mathrm{~km}$ NNW of Zagora, W of Jbel Bou Dehir) have yielded a less diverse assemblage, dominated by gastropods and the rhombiferan Macrocystella bohemica (B. Lefebvre, pers. obs.). The fourth locality, N. of Toumiat (low cliff on the bank of a dry oued, about $2 \mathrm{~km} \mathrm{NE}$ of Z-F26), corresponds to a relatively small lens containing abundant fragments of a low diversity assemblage dominated by isolated steles (stems) of the solutan Plasiacystis mobilis, associated with pieces of large asaphid trilobites, hyolithids, and disarticulated eocrinoid stems (B. Lefebvre, pers. obs.).

The second stratigraphic interval corresponds to concretion-bearing siltstones, about 750 to $790 \mathrm{~m}$ above the base of the Ordovician succession. In the absence of graptolites, the age can be estimated roughly as late early to mid Floian, based on the associated trilobite assemblage (e.g., Ampyx sp., Asaphellus fezouataensis, Basilicus (Basiliella ?) aff. destombesi) (Vidal 1998a, b). Other elements of the fauna include bivalves, brachiopods, echinoderms (asterozoans, crinoids, edrioasteroids, eocrinoids, solutans, cornute and mitrate stylophorans), gastropods (e.g., Carcassonnella, Lesueurilla, Thoralispira), hyolithids (e.g., Cavernolites ?), and machaeridians (B. Lefebvre, pers. obs.). This assemblage occurs in fossiliferous concretions collected in two localities. The first one, Bou Chrebeb, is located about $29 \mathrm{~km} \mathrm{NE}$ of Zagora, E of Jbel Bou Dehir. It was previously mentioned in the literature either as locality "1687" (Vidal 1998a, b; Destombes 2006b), “Z-5” (Van Roy 2006), or as "Z-F25" (Sumrall \& Zamora 2011). It corresponds to two main trenches (Z-F25b, Z-F25c), several hundred meters long, excavated by local fossil traders looking for complete, three-dimensionally preserved trilobites occurring in the alumino-siliceous concretions. This site has generally yielded the most diverse fossil assemblage. The second locality, Taichoute, was also exploited by local fossil traders. It is about $90 \mathrm{~km} \mathrm{NE}$ of Zagora $(37 \mathrm{~km}$ $\mathrm{NE}$ of Tazzarine, and $16 \mathrm{~km} \mathrm{SW}$ of Alnif). Its faunal content is less diverse, and largely dominated by echinoderms (the solutan Plasiacystis mobilis, associated with the rhombiferan Macrocystella bohemica) (B. Lefebvre, pers. obs.).

\section{Preservation and taphonomy}

The study material consists of impressions and moulds of original shells, which are dissolved and preserved as empty spaces. Most specimens are fragmented, sometimes with septa imploded.

In the lower fossiliferous interval, three localities (Jbel Bou Zeroualm Z-F0; Oued Beni Zoli, Z-F5; Toumiat, Z-F26) have yielded exquisitely preserved, though 
strongly compressed, specimens of cephalopods. Taphonomic features of the associated fauna (e.g., abundant remains of soft-bodied organisms, preservation of fully articulated portions of the delicate brachioles of eocrinoids) suggest both the rapid burial (smoothering) of living communities by a sudden influx of sediment (e.g., turbidite, heavy storm), and a limited or no transport of the assemblage (Van Roy et al. 2010).

In Bou Chrebeb and Taichoute, cephalopods of the second stratigraphic interval are preserved in three dimensions within alumino-siliceous concretions. Most individuals show parts of the siphuncular mould with no traces of the chambers or of the phragmocone wall (e.g. Fig. 5K). This type of preservation is interpreted as the result of conch implosion during sinking of the dead shells, herein. A similar taphonomic scenario was interpreted in the same way by Hewitt \& Westermann (1996, fig. 8, scenario 2b) and in Kröger \& Evans (2011) for Ordovician and Silurian orthocone dominated environments. The frequent fragmentation of the conchs indicates some reworking or transport of the dead shells. This interpretation accords well with sedimentological data and taphonomic features observed on other elements of the fauna: In Ordovician times, alumino-siliceous concretions are generally associated with cold, relatively deep environmental conditions (below storm wave base), and a low rate of sedimentation (Loi \& Dabard 1999, 2002). Due to their prolonged exposure on the sea-floor, fossils preserved in concretions are often slightly disarticulated or collapsed, and encrusted by various kinds of epibionts (Bruthansova \& Kraft 2003; Vidal 1998b; Sumrall \& Zamora in press).

In locality Z-F24 cephalopod conchs and hyolithids are both clearly aligned with their apices in one direction (Fig. 3). Taphonomic features of this assemblage indicate some current influence (with a limited transportation), and probably local accumulation of material (e.g., cephalopod conchs, disarticulated specimens of solutans and large trilobites) within channels or depressions. On one specimen of Rioceras? sp. (MHNM 15690.216 c; Fig. 4) epizoans (probably ceramoporid bryozoans of the order Cystoporata; pers. comm. Andrej Ernst, Kiel) are preserved on the outer surface of the phragmocone shell. Along with a specimen of Bactroceras sandbergeri (Barrande, 1867), figured in Evans (2005, pl. 4, fig. 1) from the Dapingian Pontyfenni Formation, this is the earliest known evidence of a bryozoan overgrowth on cephalopod shells. The pores of the bryozoans are aligned in subparallel direction along the growth axis and a growth direction toward the aperture of the cephalopod shell can be identified. This is similar to the situation described in specimens from the Upper Ordovician (Kröger et al. 2009 and references therein) and potentially is evidence for a synvivo growth of the bryozoans on the shell. However, more material is needed in order to verify this interpretation. Nevertheless, considering a latest Cambrian origin of bryozoans, this occurrence indicates an early exploitation of the niche of potentially floating cephalo-

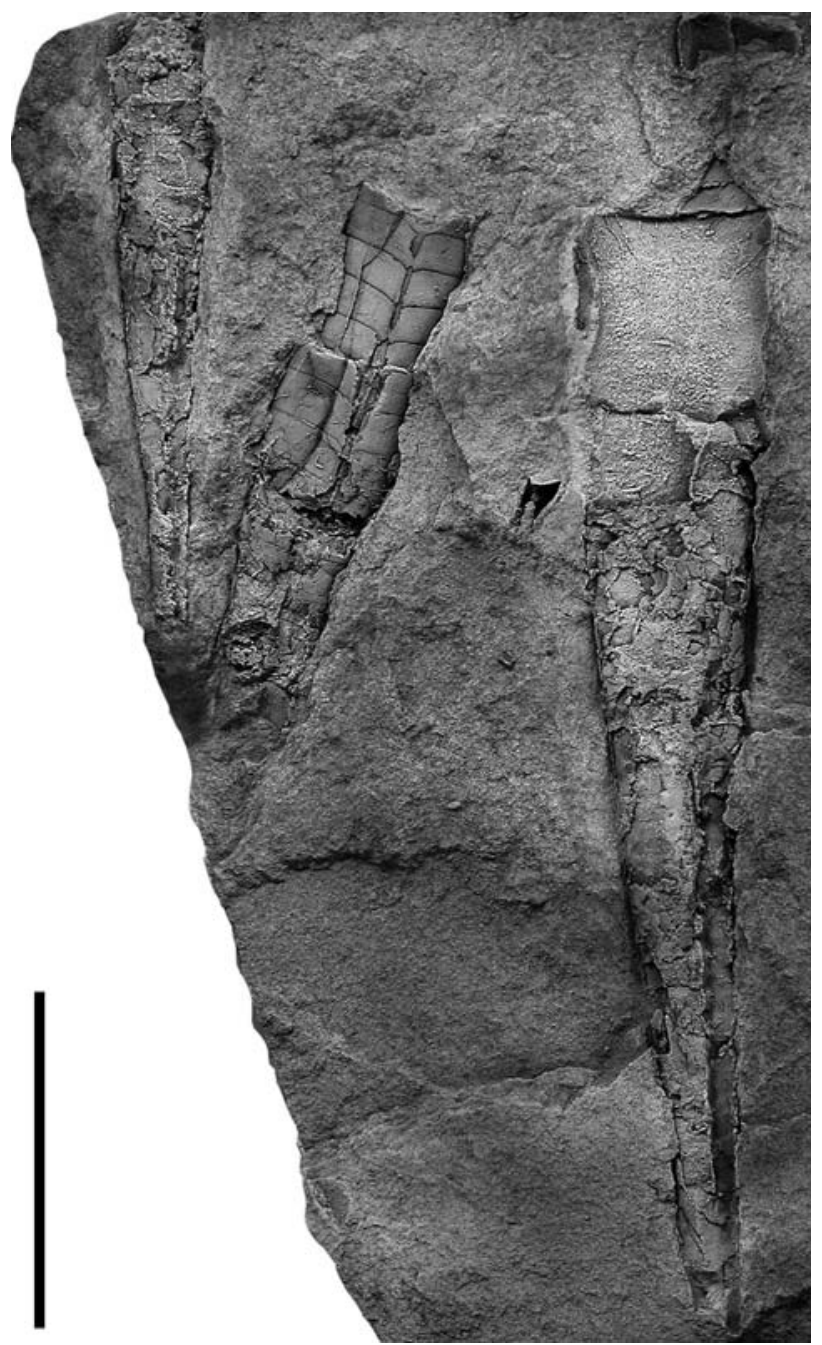

Figure 3. Aligned oriented orthoconic cephalopods from Upper Fezouata Formation, early Floian, locality Z-F24, Toumiat, near Zagora, Anti-Atlas. Specimen on the right (MHNM 15690.216a) and left (MHNM 15690.216b) are Destombesiceras zagorense n. sp., n. gen., specimen in the middle is Rioceras? sp. (MHNM 15690.216c). Scale bar $30 \mathrm{~mm}$.

pod shells early in the evolutionary history of bryozoans.

\section{Faunal composition and depositional setting}

The small collection (25 determinable specimens) of cephalopods from the Upper Fezouata Formation consists exclusively of longiconic orthocones. Fifty-six percent (14 specimens) are Destombesiceras zagorense n. gen., n. sp. This genus is a very distinctive endemic orthocone with partially expanded siphuncles and characteristic endosiphuncular deposits. The remaining cephalopods are two species of bathmocerids (3 specimens), the orthoceratoid Polymeres Murchison, 1839 (3 specimens), Rioceras Flower, 1964 (2 specimens), an unidentifiable ellesmerocerid, the orthocerid Bactroceras Holm, 1898 (1 specimen), and one specimen of the endocerid Protocyptendoceras Cecioni, 1965. 


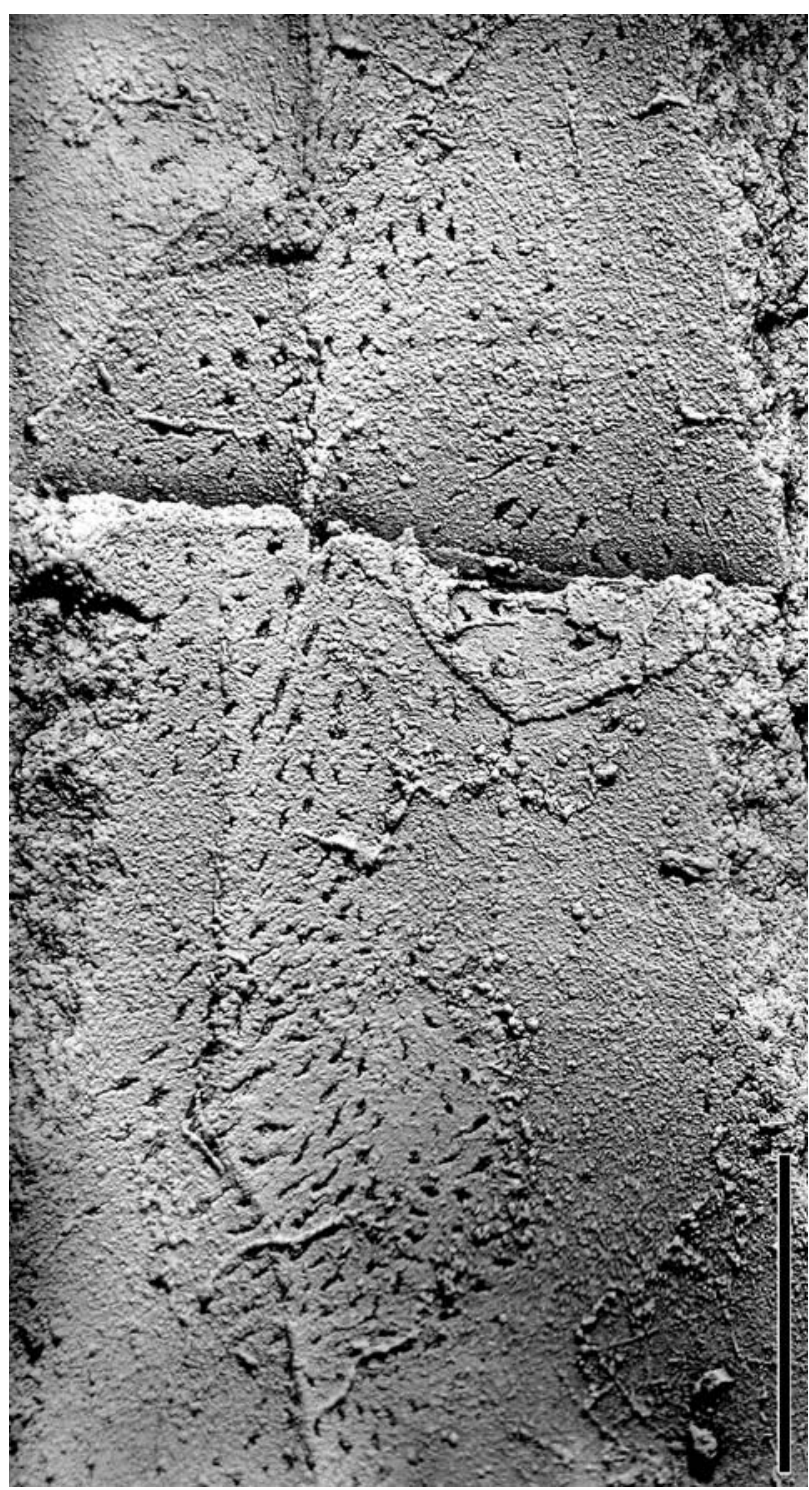

Figure 4. Internal surface of impression of Rioceras? sp., specimen MHNM 15690.216c, from Upper Fezouata Formation, early Floian, locality Z-F24, Toumiat, near Zagora, Anti-Atlas with overgrowth of probably ceramoporid bryozoans of the order Cystoporata (pers. comm. Andrej Ernst, Kiel). Scale bar $5 \mathrm{~mm}$.
Of these genera Destombesiceras, the bathmocerids and the polymerids have siphuncles with thick endosiphuncular deposits, and/or strongly thickened connecting rings. Both characters can be interpreted as beneficial for rapid buoyancy change and sensitive buoyancy regulation (see e.g., Mutvei \& Dunca, in press). It can be assumed that these forms lived as vertical migrants in open water environments. The longiconic shell indicates a relatively high strength against hydrostatic pressure (see discussion and review in Kröger et al. 2009). Based on the morphology of the cephalopods an open water association with relatively great water depths must be assumed. The occurrence of septal implosion in many shells is an additional evidence of a relatively deep, probably deeper neritic, depositional environment. This interpretation is in good accordance with both sedimentological data (e.g., presence of alumino-siliceous concretions), and the composition of both echinoderm and trilobite assemblages. For example, the co-occurrence of the eocrinoid Lingulocystis and a diverse stylophoran assemblage (comprising cornutes, kirkocystids and mitrocystitid mitrates) suggests relatively deep palaeoenvironmental conditions (mid- to outer shelf, below storm wave base), comparable to those described in the Early Ordovician of the Montagne Noire (SaintChinian and Landeyran formations; Vizcaïno \& Lefebvre 1999; Lefebvre 2007). The trilobite assemblage (e.g., Ampyx, asaphids, Basilicus) is typical of the raphiophorid biofacies (Vidal 1998a, b). This biofacies was originally described in the Early Ordovician of Wales (Carmarthen Formation; Fortey \& Owens 1978), and later documented also in the Early Ordovician of Montagne Noire (Saint-Chinian Formation; Vidal 1996). The raphiophorid biofacies is generally interpreted as typical of soft substrates in relatively deep, outer shelf palaeoenvironmental conditions. Finally, the occurrence of a rich concomitant benthic fauna (e.g., bivalves, brachiopods, gastropods, echinoderms, hyolithids, trilobites) is indicative of good living conditions at the bottom.

The cephalopod assemblage of the Upper Fezouata Formation is interpreted here mainly as (par-)autochtho-

Table 1. Diversity estimates of the cephalopod association of the Upper Fezouata Formation (early-mid Floian), Anti Atlas, Morocco compared with the St. Chinian and La Maurerie formations (late Tremadocian-early Floian), Montagne Noire, France. Note the similarity of the evenness and richness estimates in the St. Chinian and Fezouata Formation. S $\mathrm{S}_{\text {obs}}$, observed species richness; $S_{\text {Chaol }}$, Chao 1 richness estimator; $S_{\text {rarified, }}$ rarified species richness with census of 18 specimens; $D_{\text {Simpson, }}$, Simpson diversity index (inverted), (Magurran 2004: 115); $\mathrm{J}$ evenness $\mathrm{J}=\mathrm{H}^{\prime} / \log (\mathrm{S})$; where $\mathrm{H}^{\prime}$ is the Shannon-Wiener index of the sample.

\begin{tabular}{lllc}
\hline & Upper Fezouata Fm & La Maurerie Fm & St. Chinian Fm \\
\hline S Chaol (lower - upper 95\% confidence) & $13(9-40)$ & $8(7-15)$ & $10(10-11)$ \\
DSimpson (inverted) & 4.78 & 1.77 & 6.23 \\
Sobs $_{\text {S }}$ & 8 & 7 & 10 \\
Jarified (lower - upper 95\% confidence) & 8 & $4(2-6)$ & $7(5-9)$ \\
\hline
\end{tabular}


nously deposited. Potentially water currents induced local concentrations and the alignment of the dead shells (locality Z-F24). The faunal deposition and general morphology of the cephalopods, as well as the depositional environment can be best compared with both the Saint-Chinian (late Tremadocian) and La Maurerie (latest Tremadocian - early Floian) formations of Montagne Noire (Kröger \& Evans 2011) (Table 1).

The diversity of the La Maurerie Formation is significantly lower, but a great similarity exists in diversity estimates and evenness between the St. Chinian Formation and the Upper Fezouata Formation, which is in concordance with the interpretation of the relatively deep depositional environments in both formations. The St. Chinian Formation is interpreted as a transgressive interval deposited below storm wave base in an outer platform environment (Álvaro et al. 2003). The same interpretation was proposed for the Upper Fezouata Formation (Vidal 1998a, b).

The taxonomic composition of the cephalopod assemblage of the Upper Fezouata Formation is distinctive and differs from that of the Montagne Noire. The dominance of the endemic Destombesiceras and the abundance of Bathmoceras is remarkable. Bactroceras, Rioceras are known from both the Montagne Noire and the Anti-Atlas. These two genera appear to be a common element of several Early Ordovician Gondwanan cephalopod associations, further supporting the socalled "Saloceras-realm" (Kröger \& Evans 2011). Potentially, Bathmoceras australe Teichert, 1939, which occurs in Australia and possibly in Argentina (see below), Polymeres, which otherwise is known from early Floian sediments of Wales (Evans 2005), and Protocyptendoceras, which is known now from Morocco and Argentina (Cichowolski 2009) are additional elements of the Saloceras-realm.

In conclusion, our data demonstrate that taxonomically highly diverse, but morphologically monotone cephalopod associations are characteristic for high palaeolatitude Early Ordovician depositional settings. These associations appear to be most diverse in relatively deep waters. Distinctive slender orthocones dominated these associations. This is in strong contrast to the morphologically more diverse cephalopod faunas of shallow palaeotropical settings.

\section{Systematic palaeontology}

\section{Class Cephalopoda Cuvier, 1797 Order Ellesmerocerida Flower in Flower \& Kummel, 1950 \\ Family Bathmoceratidae Gill, 1871}

\section{Bathmoceras Barrande, 1865}

Type species. Orthoceras complexum Barrande, 1856; by monotypy.

Diagnosis. Straight or very weakly curved longicones with siphuncle on convex side of conch curvature. Conch cross-section circular, moderately depressed or slightly compressed. Shell smooth or annulate, sometimes with distinctive fine growth lines. Sutures nearly straight and almost directly transverse, forming a distinct $v$-shaped ventral saddle. Siphuncle c. $0.2-0.25$ of phragmocone diameter and marginal in position. Septal necks suborthochoanitic to cyrtochoanitic. Connecting ring thickened, with concavo-convex segments. Endosiphuncular ridges form narrow intrusions and chevron-like forward projecting lobes within the siphuncle. Apically a solid layer of endosiphuncular deposits occurs (after Furnish \& Glenister 1964, K156, Mutvei in press).

\section{Bathmoceras australe Teichert, 1939}

Figures 5F, 6

1939 Bathmoceras australe Teichert, p. 388, pl. 24, figs 1-4. 1984 Bathmoceras australe. - Stait \& Laurie, p. 262, table 2. 1986 Bathmoceras australe. - Chen \& Teichert, p. 176.

Type locality and horizon. Larapintine series, from fossiliferous strata $2.20 \mathrm{~m}$ below top of series Horn Valley Siltstone, Horn Valley, Glen Helen, Western Macdonell Ranges, Central Australia.

Material. Specimen AA-BCBb-OI-49 from locality Z-F25b, and AABCBc-OI-4 from locality Z-F25c, Bou Chrebeb, near Zagora, AntiAtlas; Upper Fezouata Formation, late early to mid Floian.

Diagnosis. Straight conchs with apical angle of c. $10^{\circ}$, depressed conch cross section; smooth shell. Ratio cross section width/height c. 0.75 . Adult body chamber with width of c. $31 \mathrm{~mm}$ and with adoral constriction. Fifteen chambers occur in a distance similar to phragmocone width. Sutures almost directly transverse and nearly straight with v-shaped saddle over the venter. Siphuncle marginal in position, with a diameter 0.25 that of the phragmocone height.

Description. The specimen AA-BCBb-OI-49 consists of an internal mould of a $48 \mathrm{~mm}$ long fragment of a phragmocone with a width of c. $22 \mathrm{~mm}$, and a high of $15 \mathrm{~mm}$ (ratio width/height 0.75 ). The angle of expansion is difficult to measure. The height of the chamber is c. $1.2 \mathrm{~mm}$. The sutures are straight and form a ventral saddle. The siphuncle is marginal. On the mould of the siphuncle the distinctive chevron-like structures are preserved; they are formed by the strong endosiphuncular ridges. The ridges form a v-shaped lobe on the ventral side of the siphuncle and are oblique in lateral view. The preserved part of the siphuncle has a maximum expansion of 5.5-6.7 mm over a length of $11 \mathrm{~mm}$. The siphuncle is marginal in position and relatively narrow in diameter. Ridge directed adorally over the ventral surface of the siphuncle suggesting the presence of a short septal neck.

The second specimen is a taphonomically depressed, nearly tubular fragment of the phragmocone with a length of $46 \mathrm{~mm}$ a diameter of $22 \mathrm{~mm}$ and a siphuncle diameter of $56 \mathrm{~mm}$. About 13 chambers occur in a distance similar to the corresponding conch diameter.

Discussion. These specimens are assigned to Bathmoceras australe based on their relatively low apical angle, and their depressed conch cross section, which is very similar to that of the holotype of the species. Specimens assigned to Bathmoceras cf. australe from the middle Tremadocian Floresta Formation of Jujuy, Argentina are synonymised with Saloceras cf. sericeum Salter in Ramsay 1866 by Cichowolski \& Vaccari 
(2011). However, because the internal characters of the specimen described by Cichowolski \& Vaccari (2011) are very poorly known and the conch shape remains speculative, the possibility remains that the specimens from Argentina represent Bathmoceras.

Bathmoceras was considered a characteristic Dapingian - early Darriwilian genus (see discussion in e.g., Teichert 1939; Evans 2005). Therefore, the occurrence of Bathmoceras australe in the Larapintine Series led Teichert (1939) to conclude that the type horizon must be early Darriwilian. Cooper (1981) suggests a late Floian - early Dapingian age for the Horn Valley Siltstone (Oepikodus evae to Baltoniodus navis/triangularis Conodont Zones; see Zhen et al. 2003). The specimen described herein extends the range of Bathmoceras toward the early Floian.

Stratigraphic and geographic occurrences. Floian early Dapingian, central Australia, Morocco.

\section{Bathmoceras taichoutense $\mathbf{n}$. sp.}

Figure 5D

Derivation of name. Referring to the type locality of the holotype.

Holotype. Specimen ML20-269266.

Type locality and horizon. Locality Taichoute, Anti-Atlas; Upper Fezouata Formation, late early to mid Floian.

Material. Holotype only.

Diagnosis. Slender, straight to slightly curved, annulate conchs; cross section depressed with ratio conch width/height 0.8 ; annulations form shallow lobe at prosiphuncular side, c. 5 annulations per distance similar to conch width; sutures directly transverse narrowly spaced c. 15 per corresponding conch width; siphuncle marginal with diameter 0.25 of conch height; siphuncle with distinctive endosiphuncular ridges that form chevron-like forward projecting lobes within the siphuncle.

Description. The holotype consists of the internal mould of a fragment of phragmocone with a total length of $46 \mathrm{~mm}$. The length of the preserved internal mould is $23 \mathrm{~mm}$ with a maximum width of $15 \mathrm{~mm}$ and a minimum width of $14 \mathrm{~mm}$ (apical angle $3^{\circ}$ ). The conch cross-section is depressed, its width is $15 \mathrm{~mm}$ at height $12 \mathrm{~mm}$ (ratio width/height 0.8 ). Six annulations are present at the mould, which are nearly straight and transverse, forming a very weak and wide ventral lobe. No growth lines are visible on the impression of the outer shell. The sutures are essentially straight. A v-shaped lobe exists on the venter over the position of the siphuncle. The septa are very narrowly spaced with a distance of $1 \mathrm{~mm}$ at a conch width of $15 \mathrm{~mm}$.

The diameter of the siphuncle is $3 \mathrm{~mm}$ at a conch width of $15 \mathrm{~mm}$, its position is marginal. The mould of the siphuncle shows distinctive v-shaped lobes on the ventral side and deep endosiphuncular ridges.

Stratigraphic and geographic occurrences. Upper Fezouata Formation, late early to mid Floian, Anti-Atlas, Morocco.
Discussion. This new species of Bathmoceras is characterized by its very low apical angle and its prominent annulation. Both characters are unique within the known species of Bathmoceras. The deep endosiphuncular lobes form the characteristic v-shaped pattern of the siphuncle of Bathmoceras.

Evans (2005, pl. 4, fig. 5) figured a specimen from the Whitlandian (late Floian - early Dapingian) of the Afon Ffinnant Formation of Wales, UK that he assigned to Semiannuloceras abbeyense Evans, 2005 which is not in line with the diagnosis of this species. It has a very narrow septal spacing and shows a sharp, v-shaped ventral saddle of the suture. Both features are a characteristic of Bathmoceras. The specimen figured by Evans (2005) also has a very distinctive annulation, which resembles Bathmoceras zagorense n. sp., described herein, and it probably represents a fragment of the latter. However, the fragmentary character of the specimen figured by Evans (2005) allows no definite species assignation.

Family Rioceratidae Kröger \& Evans, 2011

\section{Rioceras Flower, 1964}

Type species. Rioceras nondescriptum Flower, 1964, by original designation. From the Victorio Formation of the El Paso Group of New Mexico, southwestern United States.

Diagnosis. Small slender orthocones expanding at rates between $5^{\circ}$ and $25^{\circ}$; circular to slightly compressed or depressed cross-sections; shell smooth; sutures generally straight and directly transverse; camerae shallow, depth 0.1-0.2 dorsoventral diameter of phragmocone; body-chamber simple, tubular or faintly fusiform; septal necks loxochoanitic-orthochoanitic; siphuncle marginal, with diameter of about 0.4-0.1 of dorsoventral phragmocone diameter, segments concave with moderately thick connecting rings; endosiphuncular deposits strongly reduced or not present (from Kröger \& Evans, 2011).

\section{Rioceras sp.}

\section{Figure $5 \mathrm{~K}$}

Material. Two specimens AA-BCBb-OI-38 and FSL 711706 from locality Z-F25b, Bou Chrebeb, near Zagora, Anti-Atlas, Upper Fezouata Formation, late early to mid Floian.

Description. The specimen AA-BCBb-OI-38 consists of a portion of phragmocone increasing in diameter from $33 \mathrm{~mm}$ to $37 \mathrm{~mm}$ over a distance of $55 \mathrm{~mm}$ (angle of expansion $4^{\circ}$ ). The conchs of both specimens are slightly crushed and are slightly depressed in cross section. No signs of ornamentation are visible in the two specimens described. The chamber distance is narrow varying between 0.15 (AA-BCBb-OI-38) and 0.17 (FSL 711706) of the corresponding diameter. The sutures are directly transverse and straight. The siphuncle is marginal with a diameter of 0.15 (AA-BCBb-OI-38) and 0.13 (FSL 711706) of the corresponding conch diameter, respectively. The connecting ring is poorly preserved in both specimens, but a generally concave outline of the siphuncular segments and orthochoanitic septal necks are visible in both fragments. 


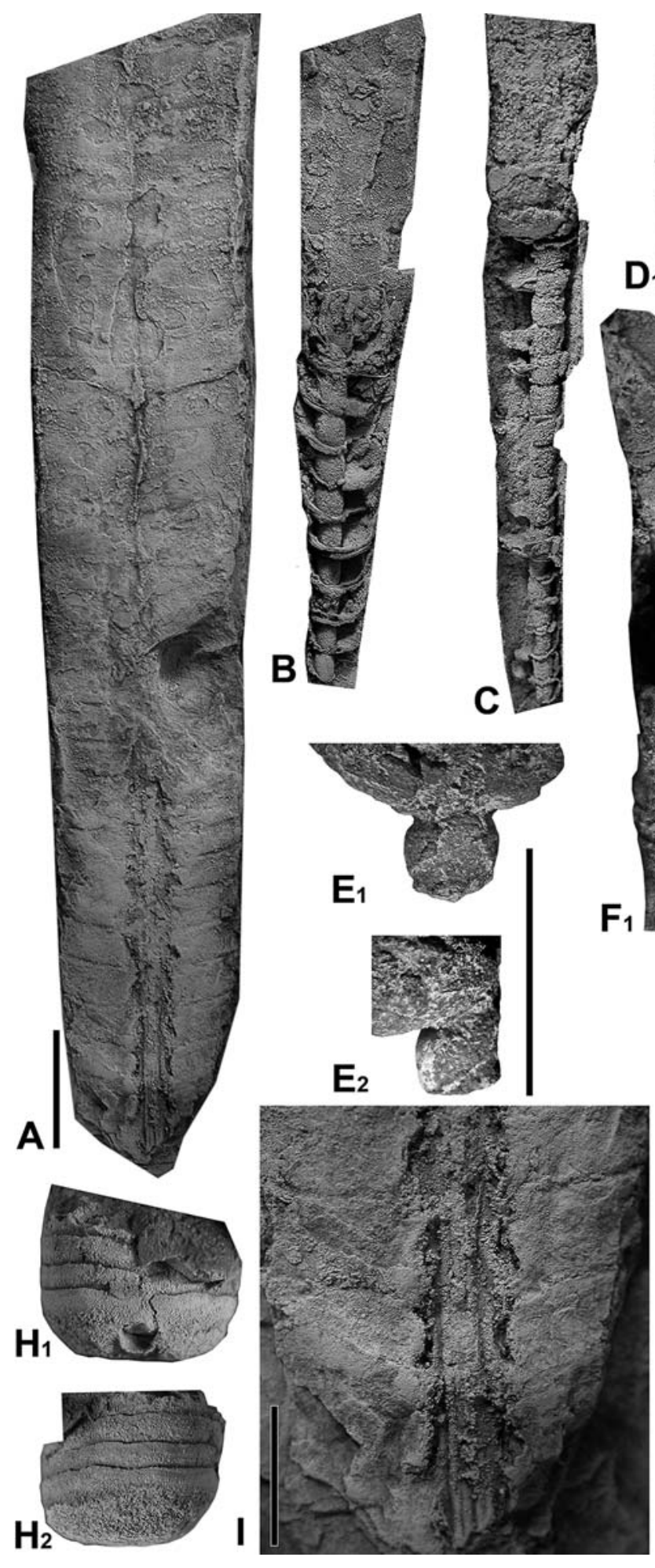

Stratigraphic and geographic occurrences. Upper Fezouata Formation, late early to mid Floian, Anti-Atlas, Morocco.

Discussion. The two specimens are assigned to Rioceras based on their general conch morphology and the thin empty, marginal siphuncle with concave siphuncular segments. Because details of early growth stages and detailed characters of conch cross section remain unknown in both specimens, a species-level determination is impossible.

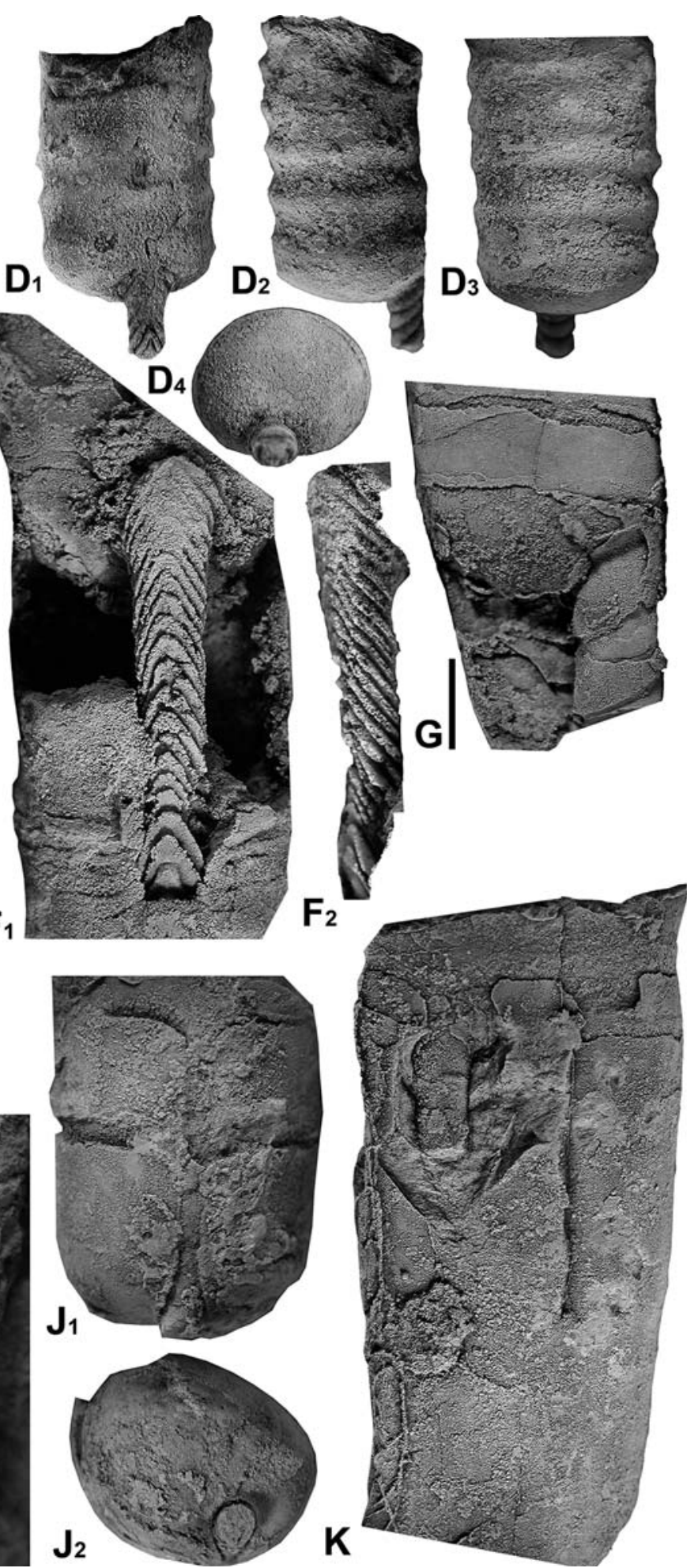

Family, genus and species indeterminate

Figure $5 \mathrm{H}$

Material. Specimen AA-BCBb-OI-39 from locality Z-F25b, Bou Chrebeb, near Zagora, Anti Atlas; Upper Fezouata Formation, early Floian.

Description. The specimen consists of a portion of phragmocone increasing in diameter from $14 \mathrm{~mm}$ to $15 \mathrm{~mm}$ over a distance of $7 \mathrm{~mm}$ (angle of expansion $8^{\circ}$ ). The short fragment appears to be part of a slightly curved conch; it is circular in cross section. No signs 
Figure 5. Cephalopods from the Upper Fezouata Formation, late early to mid Floian, Early Ordovician of central Anti-Atlas (Zagora area). A. Polymeres sp. specimen AA-OBZ-OI-29 from locality Z-F5, Oued Beni Zoli, near Zagora, ventral view, same specimen as in I, scale bar $10 \mathrm{~mm}$; B, C. Destombesiceras zagorense n. sp. from locality Z-F26, Toumiat, near Zagora, scale same as in A; B. specimen AA-BCBb-OI-42; C. specimen FSL 711703; D. Bathmoceras taichoutense n. sp., holotype, from Taichoute, AntiAtlas, $\mathrm{D}_{1}$, ventral, $\mathrm{D}_{2}$, lateral, $\mathrm{D}_{3}$, dorsal, $\mathrm{D}_{4}$, adapical view, scale same as in $\mathrm{A} ; \mathbf{E}$. Destombesiceras zagorense $\mathrm{n}$. sp., specimen FSL 711701, external details of the mould of the siphuncle, $\mathrm{E}_{1}$, ventral view, $\mathrm{E}_{2}$, lateral view, note the concave connecting ring portion at the ventral side, scale bar $10 \mathrm{~mm}$; F. Bathmoceras australe Teichert, 1939, specimen AA-BCBb-OI-49 from locality ZF25b, Bou Chrebeb, near Zagora, $\mathrm{F}_{1}$, ventral view, $\mathrm{F}_{2}$, detail of siphuncle in lateral view, scale same as in A; G. Protocyptendoceras longicameratum n. sp., holotype, locality Z-F25b, Bou Chrebeb, near Zagora, lateral view, scale bar $10 \mathrm{~mm}$; H. Ellesmerocerida indet., specimen AA-BCBb-OI-39 from locality Z-F25b, Bou Chrebeb, near Zagora, $\mathrm{H}_{1}$, ventral view $\mathrm{H}_{2}$, lateral view below, note the slightly oblique, narrowly spaced sutures, scale same as in A; I. Polymeres sp., same specimen as in A, detail of the apical part of the siphuncle, note the tubular endosiphuncular structures, scale bar $5 \mathrm{~mm}$; J. Bactroceras sp., specimen FSL 711707 from locality Z-F25b, Bou Chrebeb, $\mathrm{J}_{1}$, ventral view, $\mathrm{J}_{2}$, adapical view, note the wide septal spacing and the tubular shape of the siphuncle, scale same as in F; K. Rioceras sp., specimen AA-BCBb-OI-38 from locality Z-F25b, Bou Chrebeb, near Zagora, near ventral view, scale same as in G.

of ornamentation are visible. Four chambers are preserved with an average distance of 0.08 of the corresponding conch diameter. The sutures are directly transverse and form shallow lateral lobes. The siphuncle is marginal with a diameter of 0.17 of the corresponding conch diameter. Traces of the connecting ring indicate a concave shape of the siphuncular segments.

Discussion. This poorly preserved small fragment has a very narrow septal spacing and a marginal siphuncle with concave siphuncular segments, both characters are indicative of the Ellesmerocerida. However, the details of the ornamentation, endosiphuncular deposits and the general outline of the conch are unknown.

Order Discosorida Flower in Flower \& Kummel, 1950 Family Apocrinoceratidae Flower in Flower \& Teichert, 1957

\section{Destombesiceras n. gen.}

Deriviation of name. In honor of Jacques Destombes, who mapped the whole Anti-Atlas between 1959 and 1985, established the detailed stratigraphy of the Moroccan Ordovician series, and collected the large palaeontological collections available for study.

Type species. Destombesiceras zagorense n. gen., n. sp. from the Upper Fezouata Formation, late early to mid Floian, Anti-Atlas, Morocco.

Diagnosis. Smooth, slightly curved longicones expanding at approximately $7^{\circ}$; sutures directly transverse, $3-4$ in a distance equal to the corresponding phragmocone diameter; siphuncle marginal at concave side of conch curvature, diameter approximately 0.3 of phragmocone diameter; segments slightly concave on the side closest to the conch wall and convex on the side closest to the conch axis; septal necks suborthochoanitic with length of c. 0.3 of chamber height; parietal endosiphuncular deposits on portion directed toward conch center. In apical portions thick porous deposits on outer surface of connecting ring on side closest to conch axis.

Comparison. Destombesiceras n. gen. is unique with regard to its siphuncular shape and siphuncular wall morphology. No other orthocones with concavo-convex siphuncular segments (segments that with convex and concave sections) are known that have a similarly thickened siphuncular wall. As the calcareous thickening of the siphuncular wall extends beyond the tip of the sep- tal neck inside the siphuncle; it must be interpreted as an endosiphuncular lining, inside the connecting ring (Fig. 6). Similar endosiphuncular deposits are known from Apocrinoceratidae such as Glenisteroceras Flower, 1957, and from Bathmoceras Holm, 1899 (Mutvei \& Dunca in press, fig. 3). In contrast to Bathmoceras and other eothinocerids, the connecting ring is composed of siphuncular segments that are expanded, or convex facing, toward the center of the conch. This is similar to apocrinocerids in which the siphuncular segments are expanded and the septal necks are curved. Based on the connecting ring and the presence of specific endosiphuncular deposits Destombesiceras n. gen. is placed within the Apocrinoceratidae, herein. Destombesiceras n. gen. is the only known apocrinocerid with a marginal siphuncle. Its morphology is transient between eothinocerids and apocrinocerids. Because apocrinocerids are believed to be primitive discosorids (Kröger et al. 2009), it can be speculated that the latter are related to orthoconic Ellesmerocerida. Thus, the earlier notion of Flower \&

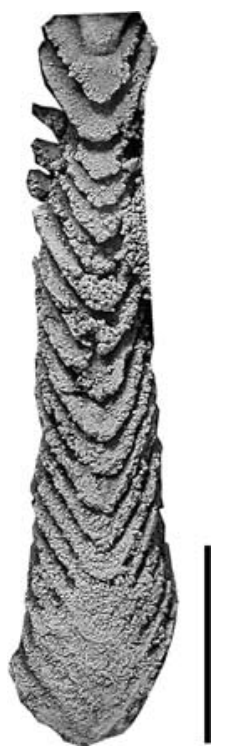

Figure 6. Siphuncle of Bathmoceras australe Teichert, 1939, specimen AA-BCBb-OI-49 from locality Z-F25b, Bou Chrebeb, near Zagora. The endosiphuncular ridges form narrow intrusions and chevron-like forward projecting lobes within the siphuncle. 
Teichert (1957: 44) that nothing suggests an ancestry of discosorids in orthoconic shells is disproved. However, this single genus Destombesiceras n. gen. is probably only a small section of a more diverse group of Floian Gondwanan orthocones with expanded siphuncles that probably also includes the poorly known Belloceras Cecioni, 1965 from Argentina. More material is needed in order to resolve the puzzle of the origin of the Discosorida and the phylogenetic relationships of the earliest Ordovician cephalopods with expanded siphuncles.

Species included. Type species only.

\section{Destombesiceras zagorense n. sp.}

Figures 3, 5B, C, E, 7-10

Deriviation of name. Referring to Zagora, the largest town near the type locality.

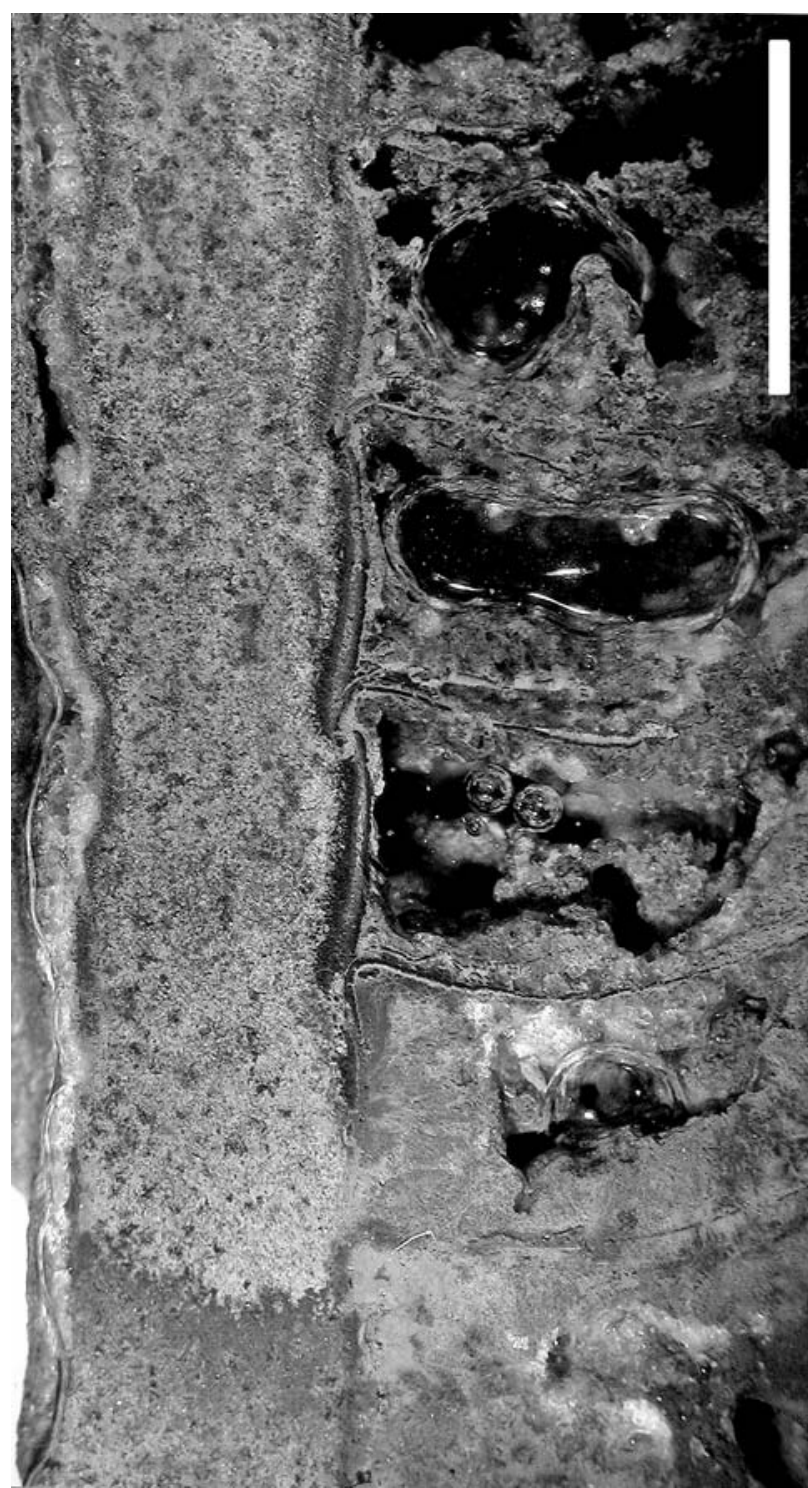

Figure 7. Median section of details of the siphuncle of Destombesiceras zagorense n. gen., n. sp., holotype, Upper Fezouata Formation, early Floian, from locality Z-F25b, Bou Chrebeb, near Zagora. Note the endosiphuncular lining and the concave shape on the marginal portion of the siphuncle. Scale bar $1 \mathrm{~mm}$.
Holotype. Specimen FSL 711700.

Paratypes. 9 specimens AA-BCBb-OI-42, -43, -47, FSL 711701, -702, $-703,-704,-705,-708$ from type locality; 3 specimens AA-TMT-OI-13, -33 , -34, from locality Z-F26, Toumiat, near Zagora, Anti- Atlas; MHNM 15690.216a, -b, from locality Z-F24, N. of Toumiat, near Zagora, Anti-Atlas, all from the Upper Fezouata Formation.

Type locality and horizon. Upper Fezouata Formation, late early to mid Floian, from locality Z-F25b, Bou Chrebeb, near Zagora, AntiAtlas, Morocco.

Diagnosis. As for genus by monotypy.

Description. The holotype is an orthoconic portion of phragmocone with a total length of $47 \mathrm{~mm}$, increasing in diameter over a distance of $34 \mathrm{~mm}$ from $13 \mathrm{~mm}$ to $16 \mathrm{~mm}$ (angle of expansion $7^{\circ}$ ). The maximum diameter of the specimen is $15 \mathrm{~mm}$. The cross section of the conch is nearly circular. Conch surface is smooth. The sutures are straight, directly transverse and distant 0.26 of the corresponding phragmocone diameter. The terminal, adoral-most septa are crowded at only $2 \mathrm{~mm}$ apart. The siphuncle is marginal in position with a diameter of $5 \mathrm{~mm}$ where the phragmocone diameter is $16 \mathrm{~mm}$ (or 0.31 of the phragmocone diameter). The siphuncular segments are slightly expanded into the chambers on the side closest to the axis of the conch, and concave into the lumen of the siphuncle on the side closest to the conch margin. The septal necks are suborthochoanitic with a length of c. 0.3 of the chamber height. Connecting ring relatively thick (Figs 7,9), and simple.
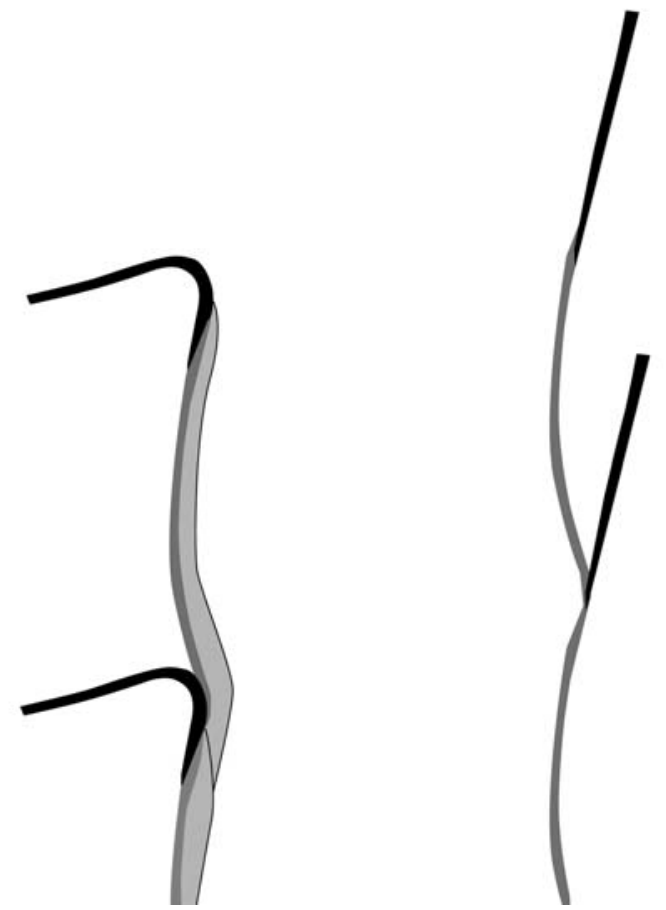

Figure 8. Schematic reconstruction of details of the septa and connecting ring of Destombesiceras zagorense n. gen., n. sp. Note the suborthochoanitc septal necks (black), the convex shape of the connecting ring (dark grey) on side closest to the conch axis. In contrast, the side of the connecting ring closest to the conch wall is concave. Also, note the endosiphuncular lining, which extends beyond the tip of the preceding septal neck (light grey). Based on holotype, see Fig. 7. 


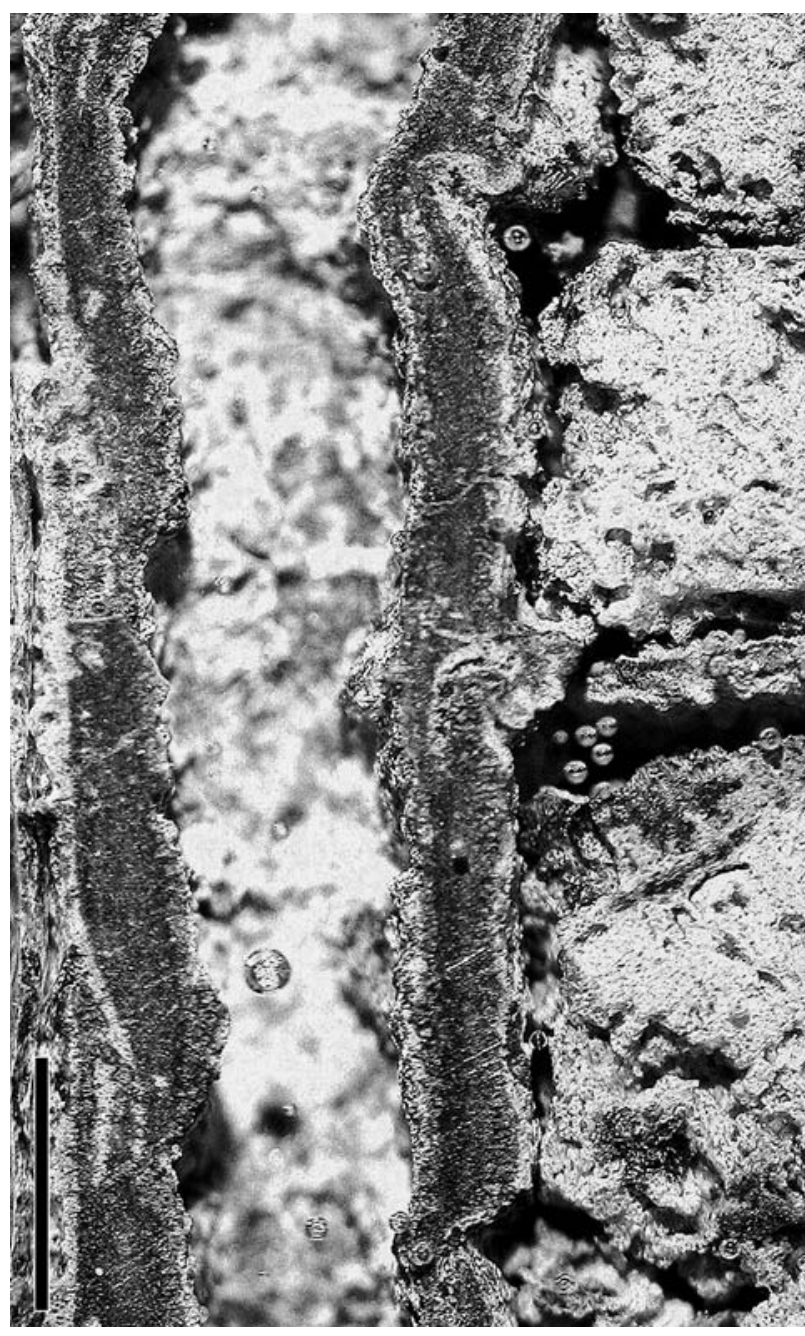

Figure 9. Median section of details of the siphuncle of Destombesiceras zagorense n. gen., n. sp., specimen AA-BCBb-OI42, from locality Z-F26, Toumiat, near Zagora. Note the thick outer layer, the endosiphuncular deposit and the concave shape on the marginal portion of the siphuncle. Scale bar $1 \mathrm{~mm}$.

The endosiphuncular deposits are segmental, reaching from the tip of the septal neck toward the inner surface of the preceding one (Figs 8, 10). They are concentrated on the side of the siphuncle closest to the axis of the conch. In apical parts of the phragmocone additionally thick, porous deposits occur on the outer surface of the connecting ring (Figs 5G, 9, 10).

The angle of expansion of the five specimens measured is in the mean $7^{\circ}$, the chamber height of 13 measured specimens is in the mean 0.27 of the corresponding conch diameter with a clear tendency of decreasing septal distance with increasing conch diameter (Fig. 3). The maximum conch diameter of an adult specimen is $18 \mathrm{~mm}$ (MHNM 15690.216b). The conch of specimen FSL 711708 is slightly curved with the siphuncle at the concave side of curvature.

Stratigraphic and geographic occurrences. Upper Fezouata Formation, late early to mid Floian, Anti-Atlas, Morocco.
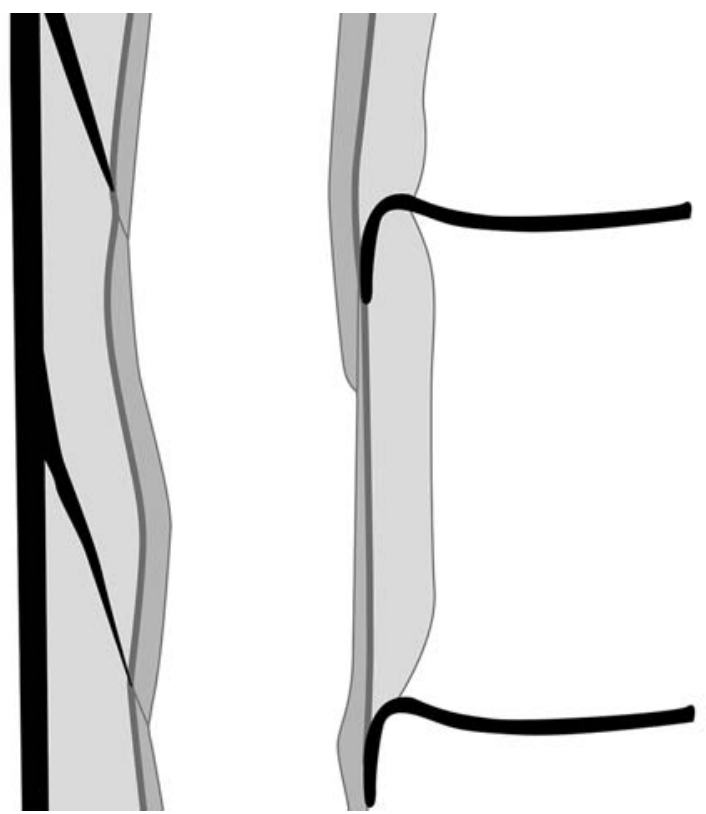

Figure 10. Schematic reconstruction of details of the septa and connecting ring of adapical part of Destombesiceras zagorense n. gen., n. sp. Note the suborthochoanitc septal necks (black), the convex shape of the connecting ring (dark grey) on side closest to the conch axis. In contrast, the side of the connecting ring closest to the conch wall is concave. Also, note the endosiphuncular lining, which extends beyond the tip of the preceding septal neck (medium grey) and the thick cameral deposits on the outside of the connecting ring (light grey). Based on specimen AA-BCBb-OI-42, see Fig. 9.

Subclass Orthoceratoidea Zhuravleva, 1994

Order Orthocerida Kuhn, 1940

Family Baltoceratidae Kobayashi, 1935

\section{Bactroceras Holm, 1898}

Type species. Bactroceras avus Holm, 1898, subsequent designation by Glenister (1952, p. 90).

Diagnosis. Slender, smooth orthocones with nearly circular cross sections; camerae generally deep; sutures straight and directly transverse; siphuncle marginal or slightly removed from conch margin, with diameter about 0.1 that of phragmocone, septal necks orthochoanitic, siphuncular segments tubular to slightly inflated with thin connecting rings; endosiphuncular deposits unknown (compiled from Holm, 1898; Evans 2005).

\section{Bactroceras sp.}

Figures 5J, 11

Material. Specimen FSL 711707 from locality Z-F25b, Bou Chrebeb, near Zagora, Anti- Atlas, Upper Fezouata Formation, late early to mid Floian.

Description. The specimen consists of a portion of two chambers of a phragmocone with a diameter of $23 \mathrm{~mm}$. The cross section is nearly circular. No signs of ornamentation are visible. The two chambers have a height of $9 \mathrm{~mm}$, respectively ( 0.35 of the corresponding diameter). The sutures are directly transverse and straight. 


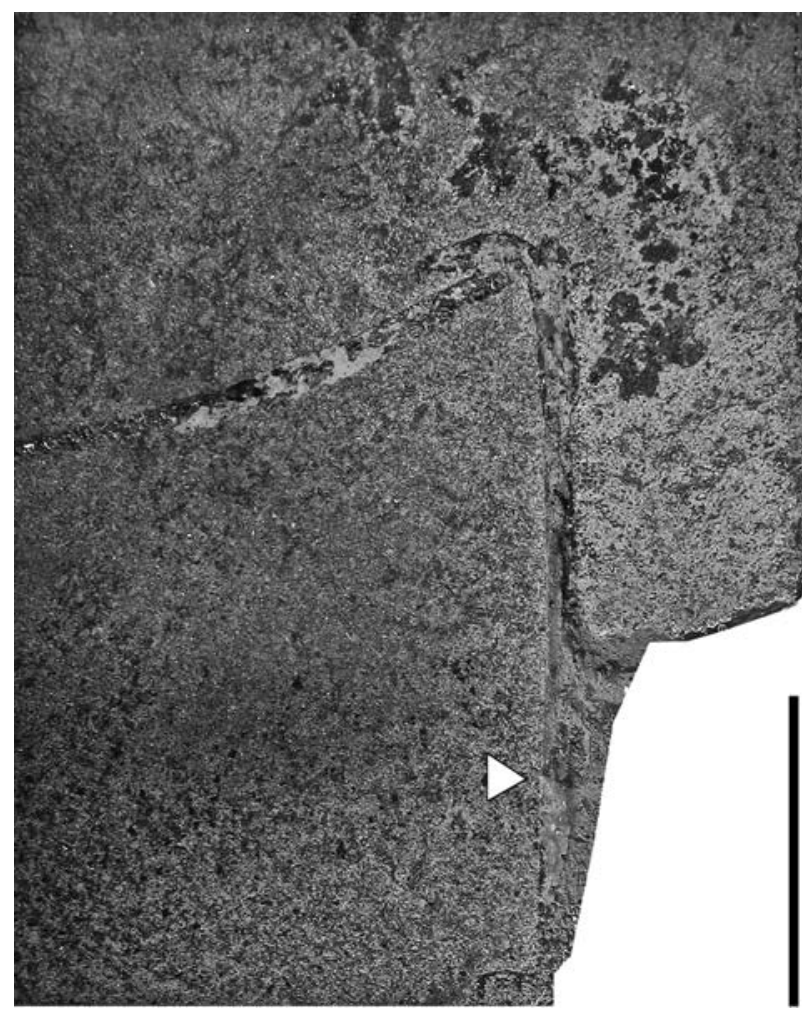

Figure 11. Median section of details of the siphuncle of Bactroceras sp. specimen FSL 711707 from locality Z-F25b, Bou Chrebeb, near Zagora, Anti-Atlas, Upper Fezouata Formation, late early to mid Floian. Note the tubular siphuncle and the orthochoanitic septal neck. Arrow marks the tip of the septal neck. Scale bar $5 \mathrm{~mm}$.

The siphuncle is marginal with a diameter of $3 \mathrm{~mm}$ ( 0.12 of the corresponding conch cross section). The connecting ring is tubular and the septal necks are orthochoanitic with a length of 0.15 of the corresponding septal distance.

Stratigraphic and geographic occurrences. Upper Fezouata Formation, late early to mid Floian, Anti-Atlas, Morocco.

Discussion. The general conch morphology and the thin marginal, tubular siphuncle, and the wide septal spacing justify an assignment to Bactroceras. The relative siphuncular diameter and the relative septal distance of the specimen described above both fall within the variability of Bactroceras angustisiphonatum (Rüdiger, 1891), but because details of the ornamentation and conch expansion are not known, a species-level determination is impossible.

Order Dissidocerida Zhuravleva, 1964

Family Polymeridae Evans, 2005

\section{Polymeres Murchison, 1839}

Type species. Polymeres demetarum Murchison, 1839, by original designation.
Diagnosis. Smooth orthocones with low moderate angle of expansion of c. $5^{\circ}$; distance of sutures in juvenile conch portions c. 0.35 of corresponding conch cross section to 0.15 in later growth stages; sutures straight and directly transverse with deep ventral lobe over siphuncle; siphuncle marginal with diameter $0.3-0.5$ of corresponding phragmocone cross-section; septal necks orthochoanitic; siphuncular segments tubular or slightly expanded with thin connecting rings; endosiphuncular deposits complex, consisting of combination of lining, annuli and a rod; episeptal hyposeptal and mural cameral deposits present, but limited to venter (compiled from Evans 2005).

\section{Polymeres sp.}

Figures 5A, I

Material. Three specimens; AA-OBZ-OI-29 from locality Z-F5, Oued Beni Zoli, near Zagora, Anti-Atlas, AA-BCBb-OI-46 from locality Z-F25b, Bou Chrebeb, near Zagora, Anti-Atlas, AA-JBZ-OI-73 from locality Z-F0, North of Beni Zoli, near Zagora, Anti- Atlas; all from Upper Fezouata Formation, late early to mid Floian.

Description. The specimen AA-OBZ-OI-29 consists of a portion of phragmocone increasing in diameter from $16 \mathrm{~mm}$ to $21 \mathrm{~mm}$ over a distance of $95 \mathrm{~mm}$ (angle of expansion $3^{\circ}$ ). The rate of expansion in AA-JBZ-OI-73 is slightly higher with $5^{\circ}$. Specimen AA-BCBb-OI-46 is essentially tubular with a diameter of c. $26 \mathrm{~mm}$. All three specimens are smooth and straight, without traces of ornamentation. The chamber distances vary between 0.3 of the corresponding diameter in the smallest conch portions (c. $6 \mathrm{~mm}$ in diameter in specimen AA-JBZ-OI73 ) and 0.13 in the largest portions (AA-BCBb-OI-46). The sutures are straight and transverse, the portions over the siphuncle are not preserved. The siphuncle is marginal in position, with a diameter of c. 0.25 of that of the phragmocone. In the apical parts of specimen AA-OBZ-OI-29 longitudinal structures in the marginal portions of exfoliated parts of the siphuncle indicate an endosiphuncular lining. The shape of the siphuncular segments is not known.

Stratigraphic and geographic occurrences. Upper Fezouata Formation, late early to mid Floian, Anti-Atlas, Morocco.

Discussion. All three specimens are poorly and fragmentarily preserved. The specimens resemble each other with respect to the low angle of expansion, narrow spacing of the septa, and the marginal siphuncle. Details of the siphuncle are not preserved except in specimen AA-OBZ-OI-29, where the shape of the siphuncular segments are not determinable. However, the tubular structures in the apical parts of the siphuncle of specimen AA-OBZ-OI-29 can be interpreted as remnants of a continuous endosiphuncular lining or a rod (Fig. 5I) similar to that of Polymeres demetarum Murchison, 1839 (see Evans 2005) from the early Floian deposits of Wales. The latter differs from the Moroccan specimens only in having a wider siphuncle. More, and better preserved material is needed for a definite species determination of the three specimens. 
Order Endocerida Teichert, 1933

Family Protocameroceratidae Kobayashi, 1937

\section{Protocyptendoceras Cecioni, 1965}

Type species. Protocyptendoceras fuenzalidae Cecioni, 1965. By original designation. Floian stage, Early Ordovician, Sepulturas Formation, La Ciénaga, Jujuy Province, Argentina.

Diagnosis. Slender orthocones with circular or subcircular section. Sutures almost straight, directly transverse with narrow ventral lobe. Moderate to large circular siphuncle in contact with ventral wall of phragmocone. Septal necks subholochoanitic and connecting rings thick. Endocones generally droplet shaped in cross section, but sometimes simply rounded (after Cichowolski 2009).

\section{Protocyptendoceras longicameratum n. sp.}

\section{Figure 5G}

Derivation of name. Referring to the septal distance, which is wide compared with the genus type species.

\section{Holotype. Specimen AA-BCBb-OI-40}

Diagnosis. Protocyptendoceras with comparatively long chamber distance of 0.38 of the corresponding diameter and narrow siphuncle of c. 0.39 of the corresponding conch diameter.

Type locality and horizon. Locality Z-F25b, Bou Chrebeb, near Zagora, Anti-Atlas, Upper Fezouata Formation, late early to mid Floian.

Material. Type specimen only.

Description. The specimen consists of a portion of a straight phragmocone increasing in diameter from $18 \mathrm{~mm}$ to $26 \mathrm{~mm}$ over a distance of $60 \mathrm{~mm}$ (angle of expansion $7.5^{\circ}$ ). The fragment is diagenetically compressed. No signs of ornamentation are visible. Eight chambers are preserved with an average distance of 0.38 of the corresponding diameter. The sutures are straight and laterally slightly inclined toward the apex at the ventral and toward the aperture at the dorsal side. The siphuncle is marginal with a diameter of 0.39 of the corresponding conch diameter. The septal necks are subholochoanitic and slightly convex, forming droplet shaped siphuncular segments. The preserved part of the siphuncle displays no signs of endosiphuncular deposits.

Discussion. The position and shape of the siphuncle and septal neck indicate that this specimen must be assigned to Protocyptendoceras. Prior to this study, this genus was only known from its type specimen from the Sepulturas Formation from Argentina. Protocyptendoceras longicameratum n. sp. differs from the type species in having a clearly more widely spaced septa and a slightly narrower siphuncle.

\section{Acknowledgements}

The authors are grateful to Kathleen Histon (Modena, Italy) and David Evans (Peterborough, UK) for their constructive comments on the MS, as well as to Roland and Véronique Reboul (Saint-Chinian) for their help in the field, to Jacques Destombes (Pessac) for providing many useful informations on local geology and stratigraphy, to Joe
Botting (Nanjing), Juan-Carlos Gutiérrez-Marco (Madrid), Radvan Horny (Prague), Peter Van Roy (Ghent), Muriel Vidal (Brest), and Daniel Vizcaïno (Carcassonne) for their help in the identification of the associated fauna, to Didier Berthet (Musée des Confluences, Lyon), Khadija El Hariri (FST Marrakech), Anne Médard and Sylvie Pichard (MHN Marseille), and Abel Prieur (University Lyon 1) for access to the specimens deposited in their collections. This paper is a contribution to the project of cooperation $n^{\circ} 22593$ between the universities of Marrakech and Lyon 1, and also to the team "Vie Primitive" of the UMR CNRS 5276.

\section{References}

Álvaro, J. J., González-Gómez, C. \& Vizcaïno, D. 2003. Paleogeographic patterns of the Cambrian - Ordovician transition in the southern Montagne Noire (France): preliminary results. - Bulletin de la Société Géologique de France 174: 217-225

Barrande, J. 1856. Bemerkungen über einige neue Fossilien aus der Umgebung von Rokitzan im silurischen Becken von Mittel-Böhmen. - Jahrbuch der kaiserlich-königlichen geologischen Reichsanstalt 7: 355-360.

Barrande, J. 1865. Système Silurien du centre de la Bohême, I.ère partie, Recherches Paléontologiques, vol. II, Classe de Mollusques, Ordre des Céphalopodes. Prague: 804.

Barrande, J. 1867. Cephalopodes. Charles Bellman, Prague and Paris.

Bigot, A. \& Dubois, J. 1931. Sur la présence de l'Ordovicien dans l'Anti-Atlas marocain. - Comptes-rendus de l'Académie des Sciences 193: 288-289.

Botting, J. P. 2007. 'Cambrian' demosponges in the Ordovician of Morocco: insights into the early evolutionary history of sponges. - Geobios 40: 737-748.

Bruthansová, J. \& Kraft, P. 2003. Pellets independent of or associated with Bohemian Ordovician body fossils. - Acta Palaeontologica Polonica 48: 437-445.

Cecioni, G. 1965. Contribucion al conocimiento de los Nautiloideoseopaleozoicos Argentinos. Parte II: Robsonoceratidae, Ellesmeroceratidae, Proterocameroceratidae, Baltoceratidae. - Boletin del Museo Nacional de Historia Natural 29: 1-24.

Chauvel, J. 1966. Echinodermes de l'Ordovicien du Maroc. Editions du CNRS, Cahiers de Paléontologie, Paris.

Chauvel, J. 1969. Les échinodermes macrocystellides de l'Anti-Atlas marocain. - Bulletin de la Société géologique et minéralogique de Bretagne 1: 21-32.

Chauvel, J. 1971a. Rhopalocystis Ubaghs: un échinoderme éocrinoïde du Trémadocien de 1'Anti-Atlas marocain. - Mémoires du Bureau de Recherches Géologiques et Minières 73: 43-49.

Chauvel, J. 1971b. Les échinodermes carpoïdes du Paléozoïque inférieur marocain. Notes du Service géologique du Maroc 31: 49-60.

Chen, J.-y. \& Teichert, C. 1986. The Ordovician cephalopod suborder Cyrtocerinina (order Ellesmerocerida). - Palaeontologia Cathayana 3: $145-229$.

Choubert, G. 1952. Histoire géologique du domaine de l'Anti-Atlas. Notes et Mémoires du Service géologique du Maroc 100: 77194.

Choubert, G., Termier, H. \& Termier, G. 1953. Présence du genre Mimocystites Barrande dans l'Ordovicien du Maroc. - Notes et Mémoires du Service géologique du Maroc 117: 137-143.

Cichowolski, M. 2009. A review of the endocerid cephalopod Protocyptendoceras from the Floian (Early Ordovician) of the Eastern Cordillera, Argentina. - Acta Palaeontologica Polonica 54: 99109.

Cichowolski, M. \& Vaccari, N. E. 2011. The oldest record of Eothinoceratidae (Ellesmerocerida, Nautiloidea): Middle Tremadocian of the Cordillera Oriental, NW Argentina. - Geological Journal 46: $42-51$. 
Colwell, R. K. 2009. EstimateS: Statistical estimation of species richness and shared species from samples. Version 8.2. User's Guide and application published at: http://purl.oclc.org/estimates.

Cooper, B. J. 1981. Early Ordovician conodonts from the Horn Valley Siltstone, Central Australia. - Palaeontology 24: 147-183.

Cuvier, G. 1797. Tableau élémentaire de l'histoire naturelle des animaux. no publisher recorded,

Destombes, J. 1962. Stratigraphie et paléogéographie de l'Ordovicien de 1'Anti-Atlas (Maroc), un essai de synthèse. - Bulletin de la Société géologique de France 4: 453-460.

Destombes, J. 1971. L'Ordovicien au Maroc. Essai de synthèse stratigraphique. - Mémoires du Bureau de Recherches Géologiques et Minières 73: 237-263

Destombes, J. 1972. Les trilobites du sous-ordre des Phacopina de l'Ordovicien de l'Anti-Atlas (Maroc). - Notes et Mémoires du Service géologique du Maroc 240: 1-74.

Destombes, J. 2006a. Carte géologique au 1/200000 de 1'Anti-Atlas marocain. Paléozoïque inférieur. Cambrien moyen et supérieurOrdovicien- Base du Silurien. Sommaire général sur les Mémoires explicatifs des cartes géologiques au 1/200000 de 1' Anti-Atlas marocain. - Notes \& Mémoires du Service géologique du Maroc 515: $1-149$.

Destombes, J. 2006b. Carte géologique au 1/200000 de 1'Anti-Atlas marocain. Paléozoïque inférieur: Cambrien moyen et supérieur Ordovicien - base du Silurien. Feuille Zagora-Coude du Drâ. Mémoire explicatif. Notes et Mémoires du Service géologique du Maroc 273: 1-5.

Destombes, J. \& Babin, C. 1990. Les mollusques bivalves et rostroconches ordoviciens de l'Anti-Atlas marocain: intérêt paléogéographique de leur inventaire. - Géologie méditerranéenne 17: 243261.

Destombes, J. \& Willefert, S. 1959. Sur la présence de Dictyonema dans le Trémadoc de 1'Anti-Atlas (Maroc). - Comptes-rendus de l'Académie des Sciences 249: 1246-1247.

Destombes, J., Hollard, H. \& Willefert, S. 1985. Lower Palaeozoic rocks of Morocco. In Holland, C. H. (ed.). Lower Palaeozoic Rocks of the World. John Wiley \& Sons, New York: pp. 91-336.

Deunff, J. 1968a. Arbusculidium, genre nouveau d'acritarche du Trémadocien marocain. - Comptes-rendus sommaires de la Société géologique de France 3: 101-102.

Deunff, J. 1968b. Sur une forme nouvelle d'acritarche possédant une ouverture polaire (Veryhachium miloni) et sur la présence d'une colonie de Veryhachium dans le Trémadocien marocain. - Comptes-rendus de l'Académie des Sciences 267: 46-49.

Donovan, S. K. \& Savill, J. J. 1988. Ramseyocrinus (Crinoidea) from the Arenig of Morocco. - Journal of Paleontology 62: 283-285.

Elaouad-Debbaj, Z. 1984. Acritarches et chitinozoaires de l'ArenigLlanvirn de l'Anti-Atlas (Maroc). - Revue de Paléobotanique et de Palynologie 43: 67-88.

Elaouad-Debbaj, Z. 1988. Acritarches et chitinozoaires du Trémadoc de l'Anti-Atlas central (Maroc). - Revue de Micropaléontologie 31: $85-128$.

Evans, D. H. 2005. The Lower and Middle Ordovician cephalopod faunas of England and Wales. - Monograph of the Palaeontographical Society 628: 1-81.

Flower, R. H. 1964. The nautiloid order Ellesmeroceratida (Cephalopoda). - New Mexico Institute of Mining and Technology, State Bureau of Mines and Mineral Resources, Memoir 12: 1-164.

Flower, R. H. \& Kummel, B. 1950. A classification of the Nautiloidea. - Journal of Paleontology 24: 604-616.

Flower, R. H. \& Teichert, C. 1957. The cephalopod order Discosorida. - University of Kansas Paleontological Contributions, Art. 21 (Mollusca, Art. 6): 1-144.

Fortey, R. A. \& Owens, R. M. 1978. Early Ordovician (Arenig) stratigraphy and faunas of the Camarthen district, south-west Wales. - Bulletin of the British Museum (Natural History), Geology 30: 225-294.
Furnish, W. M. \& Glenister, B. F. 1964. Nautiloidea-Tarphycerida. In Teichert, C. (ed.). Geological Society of America and the University of Kansas Press, Boulder, Colorado: pp. K343-K368.

Gill, T. 1871. Arrangement of the families of the Mollusca. - Smithsonian Miscellaneous Collections 227: 1-49.

Glenister, B. F. 1952. Ordovician nautiloids from New South Wales. Australian Journal of Science 15: 89-91.

Gnoli, M. \& Pillola, G. L. 2002. The oldest nautiloid cephalopod of Sardinia: Cameroceras cf. vertebrale (Eichwald, 1860) from the Arenig (Early Ordovician) of Tacconis (South East Sardinia) and remarks on the associated biota. - Neues Jahrbuch für Geologie und Paläontologie, Monatshefte 2002 (1) 1: 19-26.

Gutiérrez-Marco, J. C., Destombes, J., Rabano, I., Acenolaza, G. F., Sarmiento, G. N. \& San Jose, M. A. 2003. El Ordovícico Medio del Anti-Atlas marroquí: paleobiodiversidad, actualización bioestratigráfica y correlación. - Geobios 36: 151-177.

Havlicek, V. 1971. Brachiopodes de l'Ordovicien du Maroc. - Notes et Mémoires du Service géologique du Maroc 230: 1-135.

Hewitt, R. A. \& Westermann, G. E. G. 1996. Post-mortem behaviour of Early Paleozoic nautiloids and paleobathymetry. - Paläontologische Zeitschrift 70: 405-424.

Holm, G. 1898. Palaeontologiska notiser II: Om ett par Bactritesliknade Untersiluriska Orthocera-former. - Geologiska Freningens i Stockholm Frhandingar 20: 354-360.

Holm, G. 1899. Palaeontologiska notiser. Om ett par Bactritesliknande Untersiluriska Orthocer-former. - Geologiska Föreningens i Stockholm Förhandlingar 20: 354-360.

Horny, R. J. 1997. Ordovician Tergomya and Gastropoda (Mollusca) of the Anti-Atlas (Morocco). - Sbornik Narodniho Muzea v Praze 53: $37-78$.

Kobayashi, T. 1935. On the phylogeny of the primitive nautiloids with description of Plectronoceras liaotungense and Iddingsia? shantungensis, new species. - Japanese Journal of Geology and Geography 21: 17-26.

Kobayashi, T. 1937. Contribution to the study of the apical end of the Ordovician nautiloid. - Japanese Journal of Geology and Geography 14: $1-21$

Kröger, B. \& Evans, D. H. 2011. Review and palaeoecological analysis of the late Tremadocian-early Floian (Early Ordovician) cephalopod fauna of the Montagne Noire, France. - Fossil Record 14 (1) $5-34$

Kröger, B., Servais, T \& Zhang Yunbai. 2009. The origin and initial rise of pelagic cephalopods in the Ordovician. - PLoS ONE 4 (9): e7262. doi:10.1371/journal.pone.0007262.

Kuhn, O. 1940. Paläozoologie in Tabellen. Fischer Verlag, Jena.

Lefebvre, B. 2007. Early Palaeozoic palaeobiogeography and palaeoecology of stylophoran echinoderms. - Palaeogeography, Palaeoclimatology, Palaeoecology 245: 156-199.

Lefebvre, B. \& Botting, J. P. 2007. First report of the mitrate Peltocystis cornuta Thoral: (Echinodermata, Stylophora) in the Lower Ordovician of central Anti-Atlas (Morocco). - Annales de Paléontologie 93: 183-198.

Loi, A. \& Dabard, M. P. 1999. Stratigraphic significance of siliceousargilaceous nodules in Ordovician formations of the Armorican massif (France) and Sardinia (Italy). - Acta Universitatis Carolinae, Geologica 43: 89-92.

Loi, A. \& Dabard, M. P. 2002. Controls of sea-level fluctuations on the formation of Ordovician siliceous nodules in terrigeneous offshore environments. - Sedimentary Geology 153: 65-84.

Magurran, A. E. 2004. Measuring biological diversity. Blackwell, Malden, Mass.; Oxford.

Marek, J., Weber, B., Schönian, F., Egenhoff, S. O. \& Erdtmann, D. 2000. Arenig cephalopods from Bolivia. - Palaeontology Down Under 2000 Geological Society of Australia, Abstracts, 2000: 56.

Marek, L. 1983. The Ordovician hyoliths of Anti-Atlas (Morocco) Sbornik Narodniho Muzea v Praze 39: 1-36. 
Mergl, M. 1981. The genus Orbithele (Brachiopoda, Inarticulata) from the Lower Ordovician of Bohemia and Morocco. Vestnik Ustredniho ustavu geologickeho 56: 287-292.

Murchison, R. I. 1839. The Silurian System founded on geological researches in the counties of Salop, Hereford, Radnor, Montgomery, Caermarthen, Brecon, Pembroke, Monmouth, Gloucester, Worcester, and Stafford: with descriptions of the coalfields and overlying formations. John Murray, London.

Mutvei, H. in press. Shell structure and buoyancy regulation in the Ordovician nautiloid Bathmoceras (Cephalopoda) elucidating nautiloid evolution. Palaeontology.

Noailles, F., Lefebvre, B., Guensburg, T. E., Hunter, A. W., Nardin, E., Sumrall, C. D. \& Zamora, S. 2010. New echinoderm-Lagerstätten from the Lower Ordovician of central Anti-Atlas (Zagora area, Morocco): a Gondwanan perspective of the Great Ordovician Biodiversification Event. In M. Reich, J. R., Roden, V. \& Thuy, B. (eds). Echinoderm Research 2010. Universitätsverlag Göttingen, Göttingen: 77-78.

Oksanen, J., Kindt, R., Legendre, P., O’Hara, B., Simpson, G. L., Solymos, P., Stevens, M. H. M. \& Wagner, H. 2009. vegan: Community Ecology Package. http://CRAN.R-project.org/package=vegan.

Ramsay, A. C. 1866. The Geology of North Wales, with an appendix on the fossils by J. W. Salter. - Memoir of the Geological Survey of Great Britain 3: 1-381.

Rüdiger, H. 1891. Ueber die Silur-Cephalopoden aus den Mecklenburgischen Diluvialgeschieben. - Archiv des Vereins der Freunde der Naturgeschichte Mecklenburg 1891: 1-86.

Servais, T., Owen, A. W., Harper, D. A. T., Kröger, B. \& Munnecke, A. 2010. The Great Ordovician Biodiversification Event (GOBE): The palaeoecological dimension. - Palaeogeography, Palaeoclimatology, Palaeoecology 294: 99-119.

Stait, B. \& Laurie, J. 1984. Ordovician nautiloids of central Australia, with a revision of Madiganella Teichert \& Glenister. - BMR Journal of the Australian Geology and Geophysics 9: 261-266.

Sumrall, C. D. \& Zamora, S. 2011. Ordovician edrioasteroids from Morocco: faunal exchanges across the Rheic Ocean. Journal of Systematic Palaeontology 9: 425-454.

Teichert, C. 1933. Der Bau der actinoceroiden Cephalopoden. - Palaeontographica A 77: 111-230.
Teichert, C. 1939. Nautiloid Cephalopods from the Devonian of Western Australia. - Journal of the Royal Society of West Australia 25: $103-121$.

Termier, G. \& Termier, H. 1950. Paléontologie marocaine. Tome 2. Invertébrés de 1'Ere Primaire. Fascicule 3 - Mollusques. Hermann $\&$ Cie, Paris.

Ubaghs, G. 1963. Rhopalocystis destombesi n. g., n. sp. éocrinoïde de l'Ordovicien inférieur (Trémadocien supérieur) du Sud marocain. - Notes du Service géologique du Maroc 172: 25-45.

Van Roy, P. 2006. Non-trilobite arthropod from the Ordovician of Morocco. Unpublished PhD thesis, Ghent University.

Van Roy, P. \& Briggs, D. E. G. 2011. A giant Ordovician anomalocaridid. - Nature 473: 510-513.

Van Roy, P. \& Tetlie, O. E. 2006. A spinose appendage fragment of a problematic arthropod from the Early Ordovician of Morocco. Acta Palaeontologica Polonica 51: 239-246.

Van Roy, P., Orr, P. J., Botting, J. P., Muir, L. A., Vinther, J., Lefebvre, B., El Hariri, K. \& Briggs, D. E. G. 2010. Ordovician faunas of Burgess Shale type. Nature 465: 215-218.

Vidal, M. 1996. Quelques Asaphidae (Trilobita) de la Formation de Saint-Chinian, Ordovicien inférieur, Montagne Noire (France): systématique et paléoenvironnements. - Geobios 29: 725-744.

Vidal, M. 1998a. Le modèle des biofaciès à trilobites: un test dans l'Ordovicien inférieur de l'Anti-Atlas, Maroc. - Comptes-rendus de 1'Académie des Sciences 327: 327-333.

Vidal, M. 1998b. Trilobites (Asaphidae et Raphiophoridae) de 1'Ordovicien inférieur de 1'Anti-Atlas, Maroc. - Palaeontographica Abteilung A 251: 39-77.

Vinther, J., Van Roy, P. \& Briggs, D. E. G. 2008. Machaeridians are Palaeozoic armoured annelids. - Nature 451: 185-188.

Vizcaïno, D. \& Lefebvre, L. B. 1999. Les échinodermes du Paléozoïque inférieur de Montagne Noire: biostratigraphie et paléodiversité. - Geobios 32: 353-364.

Zhen, Y.-Y., Percival, I. G. \& Webby, B. D. 2003. Early Ordovician conodonts from far western New South Wales, Australia. - Records of the Australian Museum 55 (2) 2: 169-220.

Zhuravleva, F. A. 1964. New Ordovician and Silurian cephalopods from the Siberian platform. - Paleontological Journal 1964: 87100.

Zhuravleva, F. A. 1994. The order Dissidocerida (Cephalopoda). Paleontological Journal 28: 115-132. 